\title{
Home, School and the Museum: Shifting Gender Performances and Engagement with Science
}

\author{
Research has highlighted that engagement with science is highly gendered and that the \\ masculinised culture of science makes it difficult for many girls/women to engage. \\ Meanwhile, a growing body of research has explored the potential of out-of-school \\ spaces to provide more equitable engagement opportunities. In this paper, I examine \\ engagement with science among working-class, self-identified 'girly' girls aged 11-13. \\ I discuss how gender performances (Butler 1990) and engagement with science shifted \\ across science lessons, school trips and family trips to science museums. The findings \\ suggest that engagement with science is complex, contradictory and varies across \\ spaces - girls' performances of hyper-femininity supported engagement with science in \\ some spaces, but made it difficult in others. Different spaces also afforded the girls \\ different opportunities for performing gender, which in some instances opened up new \\ ways for engaging with science. I conclude by discussing the implications for more \\ equitable science education.
}

Keywords: engagement with science; gender performativity; gender intelligibility; school; family; museum 


\section{Introduction: Femininity and Science}

Science participation figures show persistent gender inequalities, which has raised economic and social justice concerns. Many well-paid, technical disciplines, such as physical sciences and engineering, remain dominated by men despite decades of efforts to increase female participation (Phipps 2008, WISE 2018, National Audit Office 2018). The patterns of participation are further stratified by ethnicity and socioeconomic background, suggesting that science participation is more challenging for some girls than it is for others (Smith and Gorard 2011). A study by Archer et al. (2012), for instance, has found that science-keen girls tended to be from advantaged socioeconomic backgrounds and performed more restrained versions of femininity. Working-class girls and those who self-identified as 'girly', on the other hand, were among the least likely to aspire to science-related education and/or employment (Archer et al. 2013, Francis et al. 2017).

There is a tension between science and femininity. It is widely accepted that science is not neutral nor does it transcend culture (Brickhouse 1994, Keller 1985). As Walkerdine $(1989,269)$ has noted, the 'rational self' commonly associated with science is 'a profoundly masculine one from which the woman was excluded'. Empirical research shows that from an early age, many young people regard science as more 'for boys/men' and 'clever' students (Archer et al. 2013, Hughes 2001, Adamuti-Trache and Andres 2008). The education research literature has consistently reported conflicts between performances of femininity and academic success, along with science more specifically (Renold 2005, Skelton, Francis, and Read 2010). Research has also suggested that 'girly' girls are sometimes denigrated by their peers and labelled 'stupid' and 'dumb', as well as positioned at odds with 'good' student subjectivities, due to associations of both working class-ness and femininity with the lack of intelligence (Reay 2001, Francis et al. 2017). 


\section{Gender Performativity and Gender Intelligibility across Spaces}

This paper examines engagement with science across different spaces through a gender lens, drawing on the theories of gender performativity and gender intelligibility (Butler 1990, 1993) and considering spaces as encompassing both physical environments and social relations (Massey 1994). Gender performances are shaped by people's experiences and interactions, and by wider social expectations (Kehily et al. 2002, Paechter 2006, Francis and Paechter 2015, Paechter 2003a). While the notion of performativity might imply that people are free to perform however they desire, Butler $(1993,232)$ has cautioned that performances are not simply a product of choice. Rather, they are produced through 'the forcible citation of a norm, one whose complex history is indissociable from relations of discipline, regulation, punishment' (Butler 1993, 232). Put simply, a person cannot simply choose how to perform gender without any regard for their physical body or the expectations associated with that particular (gendered, racialized) body, least not without risk to its perceived 'fit' with the dominant norms and expectations.

Gender production is shaped by particular social and cultural discourses that govern its intelligibility (Francis and Paechter 2015, Butler 1993). This means that some gender performances might be regarded as acceptable and desirable within a particular space, while others might be seen as breaking the social norm (such as in a form of 'rupture', see Renold and Ringrose 2008) and thus risking negative social response. Despite a recognition that contexts play an important role in how people perform gender and what performances are intelligible, there has been relatively little work focusing how gender performances might change as people move from one space to another. With this, I do not mean necessarily shifting from 'doing girl' to 'doing boy', or vice versa, but involving different performances of femininity and masculinity. Paechter (2010) has pointed out that there has been much more focus on time than there has been on space in the gender literature, and has argued that 
literature provides few theoretical tools for empirically examining the role of norms and expectations in influencing gender performances. Writing about the instabilities and disjunctures of gender performances, Paechter (2003a, 541) has stated that 'how we enact masculinities and femininities changes as we move between groups, between places and spaces, and through time' and Kehily et al. $(2002,176)$ has proposed that different 'performative spaces' support and constrain different enactments of gender.

While there seems to be a general agreement that gender is not a fixed entity, there seems to be an implication of stability for the gendered self.

... gender is in no way a stable identity or locus of agency from which various acts proceed; rather, it is an identity tenuously constituted in time - an identity instituted through a stylized repetition of acts. Further, gender is instituted through the stylization of the body and, hence, must be understood as the mundane way in which bodily gestures, movements, and enactments of various kinds constitute the illusion of an abiding gendered self. (Butler 1988, 519)

Butler $(1988,523)$ has argued that 'the body becomes its gender through a series of acts which are renewed, revised, and consolidated through', which I suggest alludes to the stability of gender through a process of 'becoming'. The illusion of gender stability can further be understood through the work on gender monoglossia and gender heteroglossia whereby 'particular, totemic, motifs from the gender matrix may be used by subjects to project monoglossia, and to mask the actual transgressive heteroglossia of their gendered performances' (Francis 2012, 11). That is, an appearance of monoglossic gender stability might hide the more complex heteroglossic multiplicity of diverse gender performances, which might risk being pathologised due to its perceived unintelligibility.

Empirical studies have predominantly focused on one bounded space, such as school, home or workplace. A handful of multi-sited studies, however, provide a valuable insight into the role of spaces for shaping gender performances. Reay's (2001) work on gender 
performances across multiple spaces has shown that girls would sometimes 'reinvent' themselves depending on their surroundings, such as whether they were interacting with their peers or with adults. Other studies tracing girls' gender performances across multiple spaces have, similarly, found that girls performed gender in one way when socialising with their girlfriends, another way while playing football after school and yet different way during a family outing (Kehily et al. 2002, Kelly, Pomerantz, and Currie 2005, Paechter 2010). Drawing on Connell's (1995) work, Paechter (2003b, 73) has argued that 'which masculinities and femininities are dominant in a particular social context can be very locally governed' and suggested that gender is performed relationally within local adult and peer communities, with respect to other local femininities, as well as in relation to wider social structures (Paechter 2006).

\section{The focus of this paper}

This paper examines engagement with science across multiple contexts. The rationale for examining multiple science learning spaces comes from the growing literature on the potential of out-of-school spaces for offering broader and better opportunities for young people to engage with science than formal education (Bell et al. 2009, Falk and Needham 2011). School science has been critiqued for often providing narrow engagement opportunities, including in terms of what gender performances are expected from students to engage with science and what forms of engagement are recognised as being the 'right' kind (Carlone 2004, Archer et al. 2017). While a number of small-scale studies, mostly based within afterschool science clubs, have demonstrated that out-of-school spaces can open up opportunities for engagement with science for young people (Calabrese Barton and Tan 2010, Rahm 2010), others have argued that these spaces often reproduce the structures that exclude non-dominant groups, including girls specifically (Feinstein and Meshoulam 2014, Dawson 
et al. 2019).

The focus of this paper is girls who consistently performed hyper-femininity within the context of school science and who self-identified as 'girly' (Francis et al. 2017, Gonsalves 2014, Paechter 2010). I adopt the framing of hyper-femininity as involving '(hetero)sexualised femininity and investments/production of the object of the masculine gaze' (Francis et al. 2017, 1098). Such performances have usually been associated with heterosexual relations, investment in physical appearance, aesthetics, flirtatiousness and popularity (Allan 2009), although it is important to note that (hyper-)femininity is not always necessarily heterosexual (Dahl 2012). Francis et al. (2017) have cautioned against the conflation of various labels used in the literature relating to the performances of 'girly' and 'emphasised' femininity (Connell 1987). They have pointed out that 'emphasised' femininity has been seen by some as including more restrained performances typical of 'good'/'nice' girls, thus relating to more traditional versions of middle-class femininity. Drawing on existing literature, I therefore use the term 'girly' to refer to performances of hyperfemininity (not encompassing performances of restrained femininity), similar to Reay's (2001) framing of 'girlies'.

In this paper, I address the following research question: How do gender performances (Butler 1990, 1993) support or hinder 'girly' girls' engagement with science across science lessons, school trips and family trips to science museums?

\section{The Research: a Multi-Sited Qualitative Study}

15 girls were recruited as part of a larger Enterprising Science project; six girls aged 11-12 from 'Northfields School' (NS) in London and nine girls aged 12-13 from 'Longdale High' (LH) in Manchester, UK. I explored the girls' engagement with science during science lessons and visits to science museums with their school and their families. Data were 
collected through observations (18 hours of science lessons, eight hours of school visits and 19.5 hours of family visits), interviews (with 14 students, 10 parents and four teachers) and discussion groups (with 10 students at the beginning and nine at the end of the school year). My focus was on how the students were engaging with science (Fredricks, Blumenfeld, and Paris 2004, Lawson and Lawson 2013), what made engagement possible/difficult, where, how and for whom. I was especially interested in the 'acts of engagement' that took place during my observations and which the students reflected on in the subsequent interviews and discussion groups. As Bempechat and Shernoff (2012) have reminded us, not all engagement is necessarily observable, hence being able to triangulate the data was particularly important (i.e., what the girls were observed doing and they later said they were doing at that time). I also kept notes on the girls' gender performances to understand how different performances offered more or less productive ways of engaging with science, and to examine if and how their gender performances may have shifted between different events.

The museum visits provided a valuable opportunity to observe girls across different activities, physical settings and social contexts (Ellenbogen 2002). The students first took part in an all-day school visit to science museums, which involved exploring various galleries, engaging with interactive exhibits, attending a science show and doing presentations about selected museum artefacts. Some of the students later returned to the museum with their families; these visits were unstructured and lasted between two and four hours. To capture multiple perspectives about engagement, I subsequently interviewed the students, their parents and their science teachers about their experience of the visits. I also collected data about the students' interests, attitudes and identity indicators, along with their demographic and family background data.

I focus on the eight girls who during the science lessons performed what I interpreted as hyper-femininity (see above for the conceptualisation of hyper-femininity and 'girly' 
girls). Seven of the girls attended the school visit to the science museums and three were observed during a family visit. I consider all the girls featuring in this paper to be workingclass, as interpreted from their parents' education and employment, although I recognise that class labelling is contentious, particularly in the case of recent migrants to the country (Savage, Bagnall, and Longhurst 2001, Erel 2010). Concurrently, these girls were among the least engaged students in the respective science classes, making them particularly interesting research subjects to focus on in terms of whether and how alternate opportunities may have made a difference in supporting their engagement with science.

I began analysing data by coding instances of dis/engagement with science and gender performances using NVivo software, paying particular attention to how girls' gender performances appeared to support and/or hinder engagement. Next, examining each of the participants separately, I looked for any shifts and changes in their engagement with science within and between lessons and museum visits. When changes were noted, I explored the circumstances that appeared to contribute to the shifts.

\section{Findings and Discussion}

\section{Performances of hyper-femininity constraining engagement with science}

The lessons I observed were dominated by a handful of confident students who would share their science-related knowledge, frequently drawing on experiences gained outside the school.

The usual few students put their hands up - Samira, four boys. (Field notes, NS science lesson)

Across the two participating science classes, the teachers' expectations were for students to behave 'appropriately', be 'really enthused' (Mr Bramley), 'very involved', 'will ask questions' and 'force explanation that goes beyond' (Mr Cohen). The dominance of these 
performances, which could be read as enactments of 'muscular intellect' (Mac an Ghaill and Redman 1997), made it difficult for other students to engage. As previous research has found, I suggest that there were few and narrow opportunities for diverse students to engage with science (Archer et al. 2017, Carlone, Scott, and Lowder 2014).

There also appeared to be little difference in the girls' gender performances and their engagement with science between the science lessons and the school visits to the science museums (apart from a few brief instances, which I discuss below, cf. Kenkmann 2011). Considering previous research, this is not surprising, as although museum provided a new physical space, school visits happen within the structure and expectations of the school (Silfver 2019, Dawson et al. 2019, DeWitt and Storksdieck 2008). Therefore, I discuss science lesson and school visits together; I examine the family visits in a separate section at the end.

Performances of hyper-femininity involved investments in physical appearance (showing off newly manicured nails, pretending to wax the upper lip during science lessons, making different hairstyles), flirting with boys, singing and performing pop songs, and taking and sharing 'selfie' photographs during the school visit. The following excerpts illustrate such performances:

Cordelia finds some sticky tape and tapes her nose down, makes funny faces to others.

[...] Cordelia is pretending to use sticky tape to wax her upper lip. (Field notes, LH science lesson)

Caitlin is spending a lot of time sorting out her long blond hair, making different hairstyles. (Field notes, NS science lesson)

Jasmine is singing and dancing in her chair. [...] Jasmine starts singing in a high pitch voice, teases [male name] who is playing with the big nails (part of the experiment). (Field notes, NS science lesson) Aliyah and Caitlin talk about selfies - Aliyah says 'I took a selfie with the boy I like' has to repeat a couple of times, as Caitlin is distracted by other exhibits. 'Let's take a 
selfie' says Aliyah, Caitlin says - 'I'm going to post it to Instagram.' (Field notes, NS school visit to a science museum)

The girls also spoke about the importance of physical appearance (e.g., Hayley: 'obviously, I like to dress up') and the key role of pop culture for peer relationships. Alimah, for instance, spoke about her friendship group, four of whom took part in this study and are included in this paper: "we have this group, called "the Beyoncé group", cos we all like Beyoncé and we all like to sing Beyoncé songs'. Read $(2011,1)$ has noted that 'gendered characteristics that are seen to be of most value to girls (often embodied by "celebrities" such as Britney and Beyoncé) often reflect socially dominant constructions of femininity'. I interpret such interest in the body, appearance and pop culture as resonating with 'flirty-fashion' femininity discussed by Renold $(2005,44)$, with 'an emphasis on attractiveness and appearance rather than activity and accomplishments' (Read 2011, 1) and the kind that reflects a highly sexualised school culture (Youdell 2005).

There were very few instances when the girls were able to perform hyper-femininity and science simultaneously within the context of school science. This was evidenced by the absence of engagement data in the observation notes and the girls' recollections of their experiences. When performances of hyper-femininity were enacted within the context of school science, they appeared to be a distraction from the science-focused activities.

Rifat and her friend spend most of their time taking and reviewing selfies when instructed to participate in an 'object hunt' activity - finding and photographing museum objects that fitted particular criteria. (Field notes, LH school visit to a science museum)

Performances of hyper-femininity were on occasions explicitly reprimanded and positioned at odds with science. In one instance, Mr Bramley told a group of girls that their behaviour was immature (that they 'reverted to childhood, no, babyhood') and that their behaviour clearly shows that they did not have 'a scientific mind'. In another instance, Mr Cohen closed down 
a student's attempt to participate in a way that appeared to devalue her hyper-femininity. Jasmine, who was not particularly keen on science but occasionally attempted to participate in class, volunteered during a classroom discussion about lightning and thunder.

Mr Cohen mentions that they [the students] might see lightning later today as there will be storms, Jasmine loudly says 'yessss!' Jasmine volunteers to answer a question, says about how 'lightning goes up'. She explains this is because 'the ground shakes sometimes'. Mr Cohen: 'what's that, a start of a song?' (Field notes, NS science lesson, July 2015)

I interpret Mr Cohen's explicit referencing of 'a start of a song' as a way to dismiss Jasmine's contribution by 'other[ing] femininity as deficient in its superficiality' (Francis, Skelton, and Read 2010, 326). I suggest that the comment may have been particularly damaging for someone like Jasmine, who was invested in pursuing a career in entertainment ('I'm getting into acting and singing and dance'). Popular culture has dominantly been framed as antagonistic to and in tension with schooling (Francis, Skelton, and Read 2010, Walkerdine 1998). Mr Cohen spoke about 'the Beyoncé group' girls in his class as only being interested in 'playing around' and 'flirting with boys', 'happy to plod along, and you know, just have fun. But not really excel, not really focus on something'. Echoing the findings reported by Carlone, Johnson, and Scott $(2015,474)$, there appeared to be 'virtually no room to be simultaneously "girly" and "scientific" at the same time'. Performances of hyper-femininity were unintelligible within a science learning space (Butler 1993).

On some occasions, the 'girly' girls in this study also explicitly rejected science. As Ms Richards has noted, the 'cool girls' in her class 'didn't want to be seen as being into science'. The following field notes provide an illustrative example of how the 'the Beyoncé group' girls encouraged a collective rejection of science in affirming the peer group belonging. 
For most of the visit, the 'research' microphone (worn by Jasmine) takes the function of a performative tool - the recording is filled with singing and evidently sarcastic comments about how 'amazing' the day is and 'we are learning so much today' (while being visibly disengaged and avoiding tasks). [...] After lunch, when the students are instructed to fill in a worksheet with facts about the exhibits, the girls run to the viewing platform, away from the researchers and the teachers. Leading the conversation, Jasmine starts speaking directly into the recorder: 'today was too fun.' She passes the microphone around the group for the other girls to record their sarcastic and negative remarks about their engagement with science and how much fun they had during the visit. (Field notes, NS school visit to the science museum)

I interpret the above excerpt as the girls locating their peer group outside the domain of science; the rejection of science appeared to serve as a strategy to affirm peer group membership. As Paechter (2006) has pointed out, girls construct femininity through negotiation with their peer groups and in relation to what is important to 'do' a girl in a particular context. Those who deviate significantly from the dominant local constructions of femininity might encounter difficulties in terms of a peer group membership. 'In recounting what is reprehensible, the group implicitly construct what they regard as desirable and acceptable.' (Kehily et al. 2002, 171). For the girls in this study, the 'reprehensible' feature appeared to be science, which they sought to distance themselves from in favour of a context where their 'value' was more easily leveraged, the peer group that celebrated popular culture.

\section{Performances of hyper-femininity (briefly) enabling engagement with science}

While performances of hyper-femininity generally afforded few opportunities for engagement with science (and in some instances, made engagement difficult), there was a handful of moments where it appeared to be possible for the girls to engage with science through performances of hyper-femininity. Specifically, this was supported by one of the science museum activities where students were encouraged to prepare and record a creative presentation about a museum object (the intervention material suggested 'documentary, 
interview, role-play, poem, song'). The below field notes illustrate how three girls presented about the Apollo rocket through a pop song with matching choreography.

One of the activities on the school visit was a creative presentation of a museum object, which students had prepared during a recent lesson. [...] Alimah, Jenifer and Caitlin stand in front of a large rocket in the middle of the busy gallery. Jenifer is clearly in charge and instructs her group to follow her lead. They begin singing: 'Apollo $10-$ That's the name - It went up to space and down again - up - and down again - down again, down again...' and then carry on with facts about the speed and size of the rocket. Mr Cohen compliments them at the end 'Brilliant work!' and gives each a fist bump. (Constructed from field notes, NS school visit to a science museum)

I suggest that the excerpt above could be read as a shift in discourses; in the context of this specific task, the girls were able to simultaneously cite multiple discourses and performances, and positioned themselves (and were positioned by their teacher) as good science students and 'girly' girls. The girls' engagement with science through performances of hyperfemininity was explicitly celebrated by the teacher (Mr Cohen: 'Brilliant work!'), suggesting that performances were seen as intelligible within the science learning space. Further to complimenting their presentation in the museum, Mr Cohen later commented on one of the girls' specifically: 'I'd say Caitlin is normally not very engaged in the classroom but then can be very engaged with that sort of activity [referring to the presentation during a science museum visit], she gets her confidence up a bit.'

The girls' performances of hyper-femininity, along with their 'popularity capital' associated with the arena of pop music (Read 2011), became resources for engagement with science. Resources related to singing, dancing and pop culture, which tend to have little value at school, were in these instances valued and recognised. Thus, I argue that the activity supported 'efforts to merge their [girls'] social worlds with the worlds of school science' (Calabrese Barton, Tan, and Rivet 2008, 68). The girls were allowed and encouraged to hybridise science with their non-science interests, skills and values, which provided them 
with different opportunities to engage with science, including through performances of hyperfemininity. An alternative reading of these data could be that the girls managed to subvert the dominant rules and created their own, alternative space during the museum visit activity, at least for a short while. I suggest that the negotiations and the shifts in positions and positiontaking were partly made possible by the degree of flexibility, which may have been enabled by the informality of the out-of-school space.

\section{Shifting gender performances during a family visit to a science museum opening up new opportunities for engagement with science}

Having discussed how performances of hyper-femininity constrained engagement with science in some spaces but supported and enabled it in another, I now turn to examine how some girls' performance shifted between the school and family context, and what this meant for their engagement with science. Specifically, I focus on Cordelia, for whom I noted the most significant change in both her gender performances and engagement with science.

Cordelia rarely engaged with science during her science lessons, visibly showed boredom and admitted to frequently having 'off lessons'. Mr Bramley described her engagement thus:

Mr Bramley: Cordelia, at the back [of the classroom], she's one of these who 'can't, like, I don't understand this, I don't want to do it' ... I think it's not science in particular, it's just school in general sort of thing that she might have a problem with. (Teacher interview, June 2015)

Cordelia, however, was not disinterested in science; she liked biology, planned to study science in the future and hoped to work in healthcare. She was strongly invested in performances of hyper-femininity, which served to accrue value and recognition among her peers (see above), yet manifested in tension with her teachers who described her as disruptive in the science classroom. Cordelia also recalled an instance when one of her teachers told her off by saying that science 'did not like her', which she found upsetting: 'How can she [the 
teacher] speak for science? Science might love me!'

In contrast to school, Cordelia adopted a 'science expert' role during the family visit, leading the group around the museum exhibitions, reading the labels and confidently explaining the science behind the objects.

Cordelia visits the science museum with her mum and two older siblings. After some encouragement, Cordelia takes on a leadership role and guides the group around the exhibitions. [...] Cordelia stops at an exhibit of a 'friction ball' and briefly explain what it is about - mentions forces and 'how easy it is to move'. She seems confident explaining this to the group. (Field notes; a family visit to a science museum)

Cordelia spoke positively about the science museum visit 'you got to actually do things, rather than just speak about it'. Cordelia's mum described her daughter's active engagement 'she led us round and spoke about the different things and everything, so yes, she's done really well. ... she like took control of it, which was a good thing'. She contrasted Cordelia's engagement at the museum with how she is at school, where she mentioned that her daughter 'doesn't have as much confidence in science'. The differences in behaviours and engagement with science between school and family were later brought up by Cordelia's teachers; Ms Richards remarked that she was 'not expecting her [Cordelia] to be one of the keen ones who would come to the museum with her family and take up an active role in explaining science'. Ms Richards commented on Cordelia's active engagement during the visit 'she was like "I'm going to tell you about the science, let's come over here"". The teachers' remarks were in stark contrast to their previous description of Cordelia as an 'apathetic' science student, and suggest a newfound recognition for her science participation.

Cordelia's performances of hyper-femininity, which were closely tied to peer status and popularity at school, appeared to be absent during the family visit. From the perspective of Butler's (1993) work, these changes (i.e., from performances of hyper-femininity in the school context to performances of 'science expert' in the family context) could be interpreted 
through the idea of gender intelligibility; the performances of hyper-femininity that were intelligible and socially desirable within a peer group may not have been intelligible within the context of family.

\section{Conclusion}

In this paper, I examined 'girly' girls' engagement with science across multiple spaces through a gender performativity and gender intelligibility lens. The findings support previous literature discussions in that performances of hyper-femininity largely sat in tension with science and were incongruent with 'good' science student subjectivities (Archer et al. 2013, Francis et al. 2017). The shifts in engagement among the 'girly' girls in my study across different spaces were therefore particularly interesting and I suggest, add valuable nuance to how we understand engagement with science.

This paper contributes to the existing research in sociology of education and science education with two key empirical findings. First, it highlights that engagement with science is complex, contradictory and can vary considerably across different spaces. Performances of hyper-femininity constrained engagement with science within some spaces but enabled it within another. This finding indicates the importance of investigating what is possible and expected within a particular space, and how a particular space might be able to open up possibilities not just for engagement with science, but specifically, for engagement with science through performances hyper-femininity. Second, this paper argues that performances of gender may change and shift across spaces and activities, adding another layer to the complexity of how gender performances support or hinder engagement with science. The findings presented in this paper thus challenge the relative stability of gender performance and engagement with science. While many people strive to present themselves as intelligible, 
coherent and stable being (or what Francis 2012 might refer to as gender monoglossic), what is intelligible varies across different spaces.

The findings also caution against dismissing some students as 'disengaged' without fully understanding the norms that dictate their lack of opportunities and the difficulties to negotiate (often multiple and co-existing) gender performances with those that are celebrated within a typical science learning space. Someone like Cordelia, whose classroom behaviours fitted poorly with the school's expectations, could easily be regarded as disengaged and disinterested in science. Indeed, she was repeatedly dismissed by her teachers. Yet, in a different space, Cordelia was able to take up a 'science expert' role and confidently engage with science-related activities and conversations. While it is beyond the scope of this study to speculate about the long-term implications of the positive moments of Cordelia's engagement and recognition, the literature suggests that moments of opportunities can play a significant role in empowering marginalised students in engaging with and positioning themselves in science (Carlone, Johnson, and Scott 2015, Calabrese Barton and Tan 2010).

In working towards more inclusive science education for all, a broad range of opportunities needs to be made available to young people. A wide range of gender performances needs to be supported as legitimate ways for engaging with science, including for the girls who perform hyper-femininity. If we can combine the affordances of different spaces when we consider the design and implementation of science education, we might be better able to support 'girly' girls and recognise their science-related endeavours.

\section{Acknowledgements}

I would like to thank participating teachers and families for taking part in this research. A further thanks goes to my wonderfully supportive $\mathrm{PhD}$ supervisors Louise Archer and Emily Dawson, the wider research team on the Enterprising Science project (Jennifer DeWitt, Heather King, Ada Mau, Effrosyni Nomikou and Amy Seakins), Anna Danielsson for comments on earlier drafts and the two 
anonymous reviewers who helped improve this paper with their generous and kind comments. This work was supported by Rosalind Driver Scholarship Fund at King's College London.

\section{References}

Adamuti-Trache, Maria, and Lesley Andres. 2008. "Embarking on and Persisting in Scientific Fields of Study: Cultural Capital, Gender, and Curriculum along the Science Pipeline." International Journal of Science Education 30 (12): 1557-1584. doi:10.1080/09500690701324208.

Allan, Alexandra Jane. 2009. " The Importance of Being a 'Lady': Hyper-Femininity and Heterosexuality in the Private, Single-Sex Primary School." Gender and Education 21 (2): 145-158. doi:10.1080/09540250802213172.

Archer, Louise, Emily Dawson, Jennifer DeWitt, Spela Godec, Heather King, Ada Mau, Effrosyni Nomikou, and Amy Seakins. 2017. "Killing Curiosity? An Analysis of Celebrated Identity Performances Among Teachers and Students in Nine London Secondary Science Classrooms." Science Education 101 (5): 741-764. doi:10.1002/sce.21291.

Archer, Louise, Jennifer DeWitt, Jonathan Osborne, Justin Dillon, Beatrice Willis, and Billy Wong. 2012. "'Balancing Acts': Elementary School Girls' Negotiations of Femininity, Achievement, and Science." Science Education 96 (6): 967-989. doi:10.1002/sce.21031.

Archer, Louise, Jennifer DeWitt, Jonathan Osborne, Justin Dillon, Beatrice Willis, and Billy Wong. 2013. "'Not Girly, Not Sexy, Not Glamorous': Primary School Girls' and Parents' Constructions of Science Aspirations." Pedagogy, Culture \& Society 21 (1): 171-194. doi:10.1080/14681366.2012.748676.

Bell, Philip, Bruce Lewenstein, Andrew W Shouse, and Michael A Feder. 2009. Learning Science in Informal Environments: People, Places, and Pursuits. Washington, DC: The National Academies Press.

Bempechat, J., and D. J. Shernoff. 2012. "Parental Influences on Achievement, Motivation and Student Engagement." In Handbook of Research on Student Engagement, edited by S. C. Reschly and C. A. Wylie. New York, NY: Springer.

Brickhouse, Nancy W. 1994. "Bringing in the Outsiders: Reshaping the Sciences of the Future." Journal of Curriculum Studies 26 (4): 401-416. doi:10.1080/0022027940260404.

Butler, Judith. 1988. "Performative Acts and Gender Constitution: An Essay in Phenomenology and Feminist Theory." Theatre Journal 40 (4): 519-531. doi:10.2307/3207893.

Butler, Judith. 1990. Gender Trouble: Feminism and the Subversion of Identity. London: Routledge.

Butler, Judith. 1993. Bodies that Matter: On the Discursive Limits of Sex. London: Routledge.

Calabrese Barton, Angela, and Edna Tan. 2010. "“It Changed Our Lives": Activism, Science, and Greening the Community." Canadian Journal of Science, Mathematics and Technology Education 10 (3): 207-222. doi:10.1080/14926156.2010.504480.

Calabrese Barton, Angela, Edna Tan, and Ann Rivet. 2008. "Creating Hybrid Spaces for Engaging School Science Among Urban Middle School Girls." American Educational Research Journal 45 (1): 68-103. doi:10.3102/0002831207308641. 
Carlone, H. B. 2004. "The Cultural Production of Science in Reform-Based Physics: Girls' Access, Participation, and Resistance." Journal of Research in Science Teaching 41 (4): 392-414. doi:10.1002/tea.20006.

Carlone, Heidi B., A. Johnson, and C. M. Scott. 2015. "Agency Amidst Formidable Structures: How Girls Perform Gender in Science Class." Journal of Research in Science Teaching 52 (4): 474-488. doi:10.1002/tea.21224.

Carlone, Heidi B., Catherine M. Scott, and Cassi Lowder. 2014. "Becoming (Less) Scientific: A Longitudinal Study of Students' Identity Work from Elementary to Middle School Science." Journal of Research in Science Teaching 51 (7): 836-869. doi:10.1002/tea.21150.

Connell, Raewyn W. 1987. Gender and Power: Society, the Person and Sexual Politics. Stanford, CA: Stanford University Press.

Dahl, Ulrika. 2012. "Turning Like a Femme: Figuring Critical Femininity Studies." NORA-Nordic Journal of Feminist and Gender Research 20 (1): 57-64. doi:10.1080/08038740.2011.650708.

Dawson, Emily, Louise Archer, Amy Seakins, Spela Godec, Jennifer DeWitt, Heather King, Ada Mau, and Effrosyni Nomikou. 2019. "Selfies at a Science Museum: Exploring Girls' Identity Performances in a Science Learning Space." Gender and Education. Advance online publication. doi:10.1080/09540253.2018.1557322.

DeWitt, Jennifer, and Martin Storksdieck. 2008. "A Short Review of School Field Trips: Key Findings from the Past and Implications for the Future." Visitor Studies 11 (2): 181-197. doi:10.1080/10645570802355562.

Ellenbogen, Kirsten M. 2002. "Museums in Family Life: An Ethnographic Case Study." In Learning Conversations in Museums, edited by Gaea Leinhardt, Kevin Crowley and Karen Knutson, 81-101. Mahwah, NJ: Lawrence Erlbaum.

Erel, Umut. 2010. "Migrating Cultural Capital: Bourdieu in Migration Studies." Sociology 44 (4): 642-660. doi:10.1177/0038038510369363.

Falk, John H, and Mark D Needham. 2011. "Measuring the Impact of a Science Center on its Community." Journal of Research in Science Teaching 48 (1): 1-12. doi:10.1002/tea.20394.

Feinstein, Noah Weeth, and David Meshoulam. 2014. "Science for What Public? Addressing Equity in American Science Museums and Science Centers." Journal of Research in Science Teaching 51 (3): 368-394. doi:10.1002/tea.21130.

Francis, Becky. 2012. "Gender Monoglossia, Gender Heteroglossia: The Potential of Bakhtin's Work for Re-Conceptualising Gender." Journal of Gender Studies 21 (1): 1-15. doi:10.1080/09589236.2012.639174.

Francis, Becky, Louise Archer, Julie Moote, Jennifer DeWitt, and Lucy Yeomans. 2017. "Femininity, Science, and the Denigration of the Girly Girl." British Journal of Sociology of Education 38 (8): 1097-1110. doi:10.1080/01425692.2016.1253455.

Francis, Becky, and Carrie Paechter. 2015. "The Problem of Gender Categorisation: Addressing Dilemmas Past and Present in Gender and Education Research." Gender and Education 27 (7): 776790. doi:10.1080/09540253.2015.1092503. 
Francis, Becky, Christine Skelton, and Barbara Read. 2010. "The Simultaneous Production of Educational Achievement and Popularity: How do Some Pupils Accomplish It?" British Educational Research Journal 36 (2): 317-340. doi:10.1080/01411920902919265.

Fredricks, Jennifer A, Phyllis C Blumenfeld, and Alison H Paris. 2004. "School Engagement: Potential of the Concept, State of the Evidence." Review of Educational Research 74 (1): 59-109. doi:10.3102/00346543074001059.

Gonsalves, Allison. 2014. "'Physics and the Girly Girl - There is a Contradiction Somewhere': Doctoral Students' Positioning Around Discourses of Gender and Competence in Physics." Cultural Studies of Science Education 9 (2): 503-521. doi:10.1007/s11422-012-9447-6.

Hughes, Gwyneth. 2001. "Exploring the Availability of Student Scientist Identities Within Curriculum Discourse: An Anti-Essentialist Approach to Gender-Inclusive Science." Gender and Education 13 (3): 275-290. doi:10.1080/09540250120063562.

Kehily, Mary Jane, Mairtin Mac An Ghaill, Debbie Epstein, and Peter Redman. 2002. "Private Girls and Public Worlds: Producing Femininities in the Primary School." Discourse: Studies in the Cultural Politics of Education 23 (2): 167-177. doi:10.1080/0159630022000000750.

Keller, Evelyn Fox. 1985. Reflections on Gender and Science. New Haven, CT: Yale University Press.

Kelly, Deirdre M., Shauna Pomerantz, and Dawn Currie. 2005. "Skater Girlhood and Emphasized Femininity: 'You Can't Land an Ollie Properly in Heels'." Gender and Education 17 (3): 229-248. doi:10.1080/09540250500145163.

Kenkmann, Andrea. 2011. "Power and Authenticity: Moving from the Classroom to the Museum." Adult Education Quarterly 61 (3): 279-295. doi:10.1177/0741713610392766.

Lawson, Michael A, and Hal A Lawson. 2013. "New Conceptual Frameworks for Student Engagement Research, Policy, and Practice." Review of Educational Research 83 (3): 432-479. doi:10.3102/0034654313480891.

Mac an Ghaill, M., and P. Redman. 1997. "Educating Peter: The Making of a History Man." In Border Patrols: Policing the Boundaries of Heterosexuality, edited by D. Steinberg, D. Epstein and R. Johnson. London: Cassell.

Massey, Doreen. 1994. Space, Place and Gender. Cambridge: Polity Press.

National Audit Office. 2018. Delivering STEM (Science, Technology, Engineering and Mathematics) Skills for the Economy. London: Department for Business, Energy \& Industrial Strategy \& Department for Education.

Paechter, Carrie. 2003a. "Learning Masculinities and Femininities: Power/Knowledge and Legitimate Peripheral Participation." Women's Studies International Forum 26 (6): 541-552.

doi:10.1016/j.wsif.2003.09.008.

Paechter, Carrie. 2003b. "Masculinities and Femininities as Communities of Practice." Women's Studies International Forum 26 (1): 69-77. doi:10.1016/S0277-5395(02)00356-4.

Paechter, Carrie. 2006. "Constructing Femininity/Constructing Femininities." In The SAGE Handbook of Gender and Education, edited by Christine Skelton, Becky Francis and Lisa Smulyan, 365-377. New York, NY: Sage. 
Paechter, Carrie. 2010. "Tomboys and Girly-Girls: Embodied Femininities in Primary Schools." Discourse: Studies in the Cultural Politics of Education 31 (2): 221-235.

doi:10.1080/01596301003679743.

Phipps, Alison. 2008. Women in Science, Engineering, and Technology: Three Decades of UK Initiatives. Sterling, VA: Trentham Books.

Rahm, Jrène. 2010. Science in the making at the margin: A multi sited ethnography of learning and becoming in an afterschool program, a garden and a math and science upward bound program. Rotterdam: Sense.

Read, Barbara. 2011. "Britney, Beyoncé, and Me-Primary School Girls’ Role Models and Constructions of the 'Popular'girl." Gender and Education 23 (1): 1-13. doi:10.1080/09540251003674089.

Reay, Diane. 2001. "'Spice Girls', 'Nice Girls', 'Girlies', and 'Tomboys': Gender Discourses, Girls' Cultures and Femininities in the Primary Classroom." Gender and Education 13 (2): 153-166. doi:10.1080/09540250120051178.

Renold, Emma. 2005. Girls, Boys, and Junior Sexualities. London: Routhledge Falmer.

Renold, Emma, and Jessica Ringrose. 2008. "Regulation and Rupture Mapping Tween and Teenage Girls' Resistance to the Heterosexual Matrix." Feminist Theory 9 (3): 313-338. doi:10.1177/1464700108095854.

Savage, Michael, Gaynor Bagnall, and Brian Longhurst. 2001. "Ordinary, Ambivalent and Defensive: Class Identities in the Northwest of England." Sociology 35 (4): 875-892. doi:10.1177/0038038501035004005.

Silfver, Eva. 2019. "Gender Performance in an Out-Of-School Science Context." Cultural Studies of Science Education 14 (1): 139-155. doi:10.1007/s11422-017-9851-z.

Skelton, Christine, Becky Francis, and Barbara Read. 2010. "“Brains Before 'Beauty’?” High Achieving Girls, School and Gender Identities." Educational Studies 36 (2): 185-194. doi:10.1080/03055690903162366.

Smith, Emma, and Stephen Gorard. 2011. "Is there a Shortage of Scientists? A Re-Analysis of Supply for the UK." British Journal of Educational Studies 59 (2): 159-177. doi:10.1080/00071005.2011.578567.

Walkerdine, Valerie. 1989. "Femininity as Performance." Oxford Review of Education 15 (3): 267279. doi:10.1080/0305498890150307.

Walkerdine, Valerie. 1998. Daddy's Girl: Young Girls and Popular Culture. Cambridge, MA: Harvard University Press.

WISE. 2018. "2018 Workforce Statistics." Accessed 25 November 2019 https://www.wisecampaign.org.uk/statistics/2018-workforce-statistics.

Youdell, Deborah. 2005. "Sex-Gender-Sexuality: How Sex, Gender and Sexuality Constellations are Constituted in Secondary Schools." Gender and Education 17 (3): 249-270. doi:10.1080/09540250500145148. 